\title{
Identity of the Baltic Seashore Cities Liepaja, Ventspils and Palanga
}

\author{
S. Ozola \\ Riga Technical University, Latvia
}

\begin{abstract}
Identity of city environment is formed by cultural heritage that encodes information about many processes in the past and needs a sustainable or balanced development. Living environment that is rich with forms and structures can satisfy individual's physical and mental needs, and inspire new ideas. To realize sustainable and balanced development of the Baltic seashore cities Liepaja, Ventspils and Palanga, structural changes are carried out using different spatial development models.

The goal of this research is to compare the models of sustainable spatial development of the Baltic seashore cities Liepaja, Ventspils and Palanga, and to assess their effects on the citizen quality of life.

KEYWORD: identity; balance; sustainable spatial development; cultural heritage
\end{abstract}

\section{INTRODUCTION}

Balts living since ancient times has been associated with the presence of the Baltic Sea and costal natural features - wind, sand and water. Human and natural relationships were developed diversified. Area population and landscape discover interaction of natural, political and economic in different conditions. Courland costal cities Liepaja, Ventspils and Palanga people's relationships with the sea had an impact on architectural quality of surrounding, which reflect understanding of the economic, culture and art; that has made the city unique. Relationships between consumers and producers down the quality of the living environment. One of the sustainable development preconditions is identity, which can be achieved by identification, preservation and restoration of cultural Heritage, natural objects and specific landscape.

Purpose: to compare the models of sustainable spatial development of cities Liepaja, Ventspils and Palanga, and to assess their effects on the citizen quality of life.

Methodology: theoretical study, compare cartographic, visual and other materials.

\section{THE REGIONAL DEVELOPMENT OF COURLAND COAST OF THR BALTIC SEA}

Latvia declared sovereignty once more on $4^{\text {th }}$ May, 1990, but on $1^{\text {st }}$ May, 2004 the Republic of Latvia became a member state of European Union. On $25^{\text {th }}$ May, 2005 European Community Commission adopted the declaration, where the main goals and basic principles of sustainable development were defined. In order to provide balanced development of urban environment it was necessary to abide partnership between state and local government institutions, non-governmental organizations and entrepreneurs. Elaborating development projects, the variety of territories in city should be maintained, to preserve industrial and culture heritage, local landscape, as well as to create contemporary cultural environment and to strengthen local identity. City sustainable development is promoted by local scale action to promote environment, social and economic improvement and to preserve identity (Jākobsone, 2011: 85). In the regions, where the historic identity is lost, people try to study, preserve and renew objects of heritage value and landscape features, as well as typical scenery, in order to design new identity. It is important not only to propose balanced development basic principles, but to implement them, that is why in the territory planning the priority should be person and his residential, providing employment, health, recreation, traffic and communal services, as well as the rational use of natural resources (Brinkkis, 2001: 10).

On $16^{\text {th }}$ February, 1991 Lithuania regained independence, but on $1^{\text {st }}$ May, 2004 the Republic of Lithuania became a member state of European Union. In Lithuania development of the Baltic seashore populated areas was solved in a complex 
way. Seaside Regional Park (1992) is founded in territory between Klaipeda (the former town of Kingdom of Prussia, was called Memel) - ice-free harbour, the centre of industry, trade, education and culture and Palanga - sea health resort with populated area Šventoji.

In the newly restored Baltic States there were changes not only in politics, economics and in social, planning and legal fields, but also in the growth of cities. There were separate models of sustainable spatial development created in order to improve the living environment quality of inhabitants in cities.

\subsection{The development model of resort city Palanga}

In Palanga the historic planning with regular street network was being preserved. At Palanga administrative territory the old road KlaipedaLiepaja has become the main street - Vytauto gatve, from which a perpendicular branch along the Ronze River - the reconstructed Jona Basanaviciaus gatve (2006) - leads to the West to the Baltic seashore. The promenade is completed renowned bridge on piles in the sea (1998). Kretingos gatve takes from the town centre to the East out of city, where there is created a detour road - Klaipedos plentas. In the resort of international significance the construction of living houses is moved to the locality of main roads by Kretingos gatve and in the territory between Vytauto gatve and Klaipedos plentas and there is a modern trade and business centre developed. Culture is a priority for Palanga. The green system created by Palanga Botanic Garden, large-scale pinewood tracts by the seashore, household gardens and squares. Lithuanian Ministry of Culture announced Palanga the Capital of Culture (2013).

Strategic development plan of Palanga reflects a long-term vision of the municipality, long-term development trends of all sectors, and is based on political, economic, social and cultural analysis. The goal of strategic plan - defines the role and significance of Palanga in Lithuanian economic and social life, evaluates ever-changing trends of development, analyzes their importance in the municipality policy, forms alternative development perspectives and recommends allocation of national and the European Union structural funds.

\subsection{The development model of port city Ventspils}

In order to promote the development of Ventspils "The territorial planning of Ventspils City" was elaborated, keeping the functional structure of territory and promoting harmonious development of environment. Well-organized Baltic Sea coast beach is surrounded by forests. Greenery system includes woods, parks and well-organized squares. Administrative borders of Ventspils City to the
South from the Venta River includes Ostgals, where Beach Water Park, South-pier Promenade, Yacht Harbour and renown theatre building "Jüras vārti" (2010, arch. Juris Poga, Astra Poga, interior Imants Rubins, Ivo Tacs) are situated. In locality of Kaziņmežs an Adventure Park and Seaside open-air museum are created. On the seashore a recreation and culture centre develops. City environment is being enriched by fountains "Saules laivinas" (2000, arch. Juris Kronbergs, sculptor Inta Berga) and flower clock (2002, author Jānis Trops).

Many business and public objects - Creative work house, the Central library of Ventspils, Digital Centre, the house of craftsmen and the international writer and translator house - are placed in Old Town. Harbour (Ostas) Street Promenade with a business centre of stock-company "Ventspils nafta" (2003, architect office Ltd. "Tugalev LTV") and city environment objects created on the coast of the Venta River. The renown castle of Livonia order is turned into culture and education centre.

The production units developed on the shore of the river, in the locality of bridges and by railroads. On the East coast of the Venta River to South from transport centre there is land allocated to societies of gardening, low-storey constructions and farmsteads. The main road roundabouts and bridge creates a link for hub on the right shore of the Venta River with the main traffic road on the left short of Ventspils reconstructed Kuldiga Street. Not far from bus station there is Water Adventure Park, as well as Olympic Centre "Ventspils" (1997).

Administrative borders of Ventspils to the North from the Venta River include territory behind harbour enterprises and production units, as well as populated area Staldzene. The popular places by tourists - coastal cliffs of Staldzene, Deer Garden and Būšnieku Lake - promote creation of the tourism centre. A part of Būšnieku Lake coast is "Natura 2000" Special Protection Area.

Historically developed low-storey construction and farmsteads dominate in Pārventa. Many-storey living houses, business and public objects are places in the locality of traffic main roads. Centre of Pārventa developed in locality of Talsu, Aviatoru (Lidotajju) and Targales streets. The main roads Embutes and Talsu streets - provide a link between hub and production units on the harbour shore, but Amber (Dzintaru) Street and Courland (Kurzemes) Street join the production units in the locality of Seaside harbour. A stock-company "Kälija parks" was created in January, 1994.

\subsection{The development model of port city Liepaja}

In Liepaja Trade and Naval Port canals have created threefold division planning (Fig. 1) - each part has a unique cultural and historical heritage, the attitude of local government is important in order to preserve 
the heritage. On $31^{\text {st }}$ August, 1994 the USSR Naval Base ceased to exist in Liepaja. The substitution of ownership created changes and promoted functional fragmentation of Liepaja planning, corresponding to the interests of individual entrepreneurs and enterprises. In a short period of time many production units were closed and the search of new urban space solutions were initiated without historic planning analysis. Many buildings were renovated, but others - were created anew, however countless architecture and cultural heritage building and green areas were gradually disappearing, leaving open spaces, where sea winds run. Historical buildings were rebuilt to hotels and guest houses, as well as used as offices. Since 2001 year in Liepaja several churches was built. Entrusting the construction of new buildings and renovation of old houses to individuals and legal entities, urban environment obtains uneven quality. In Liepaja culture, education, sports, medicine and trade fields were reorganized: several educational and medical institutions were closed, despite that the development of residential areas should be promoted, preserving little local scale culture, education, sport, medicine, trade and entertainment institutions nearby the place of residence of inhabitants.

Until March, 2009 in Liepaja city territorial planning 42 amendments were made, as well as 32 detailed plans were created and 12 more detailed plans were under development (Vitāls, 2009). While changing the functional meaning of territory in a hurry, sometimes the current construction was ignored.

The Parliament of Latvia adopted the law of Liepaja Special Economic zone on $18^{\text {th }}$ February, 1997 for the period of twenty years. Liepaja Special Economic zone was created for the development of trade, industry, shipping and air traffic, as well as for the exchange of international goods through Latvia. The detailed planning of Naval Port residential area and Naval Port industrial park was elaborated (2001). The territory of Naval Port was divided for enterprises to do the business. Protected object status was not allocated to the building complex of Naval Port Town. The military heritage was supposed to preserve in only one quarter (Liepaja, 2011: 69-97). Diver's learning centre (2001) and sport complex (2007) were built, but dockyard "Tosmare" stopped the work and the culture centre of the enterprise was closed. Temporary art gallery "K. Māksla?" local government's affiliate and police station were liquidated. Renovation are going on St. Nicholas Orthodox Sea Cathedral and building of Navy Officers' Conventions.

In North suburb constructions of new public, culture and apartment houses has not been, except supermarkets. Liepaja's sugar-refinery stopped production (2007) and the club was liquidated. Culture and sport establishments in the neighborhoods of "Lauma" residential area were rebuilt into supermarkets. In the area of Zaļa birzs residential buildings are not public centre with culture, education and trade objects.

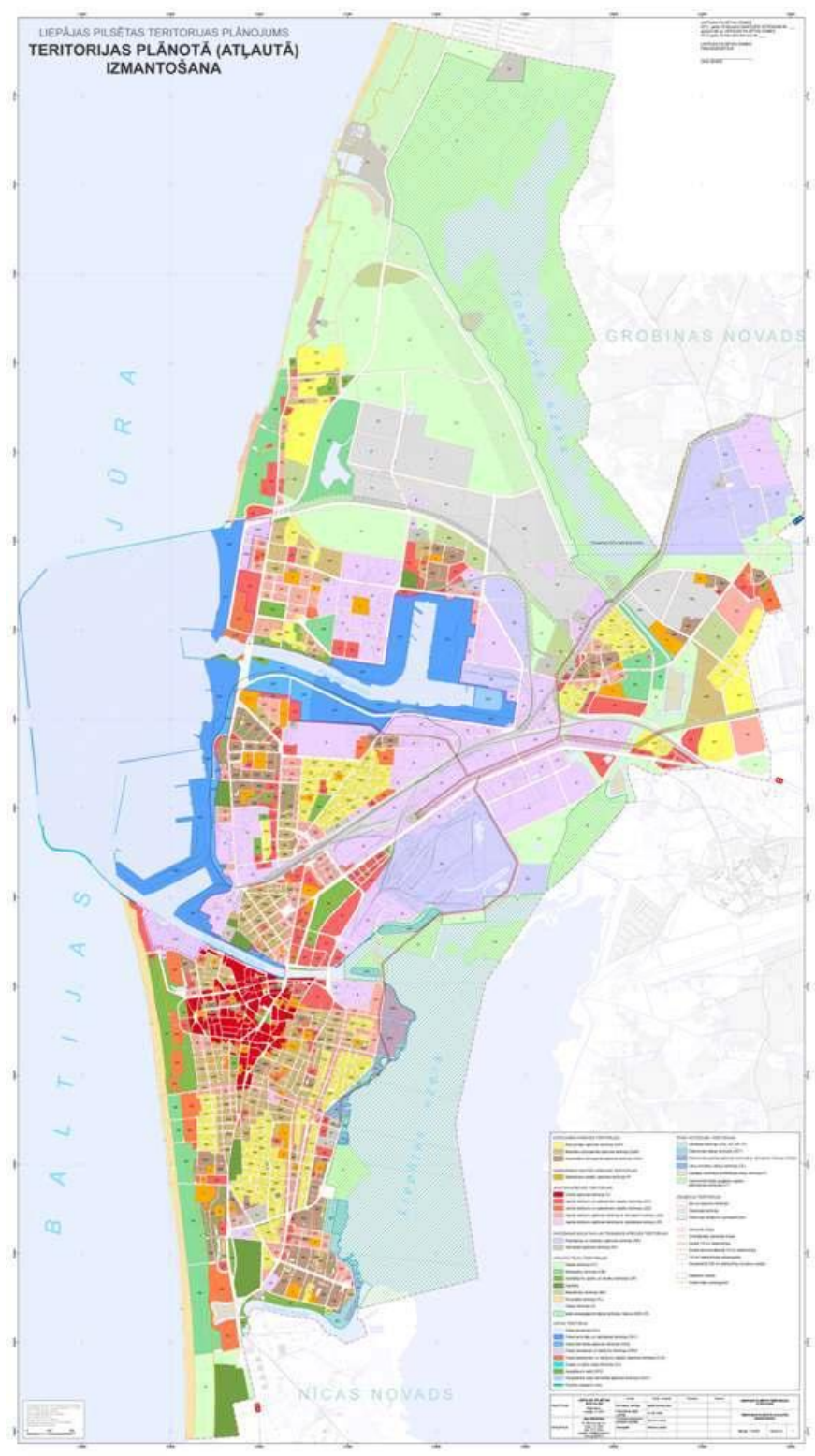

Figure 1. Liepaja. Territory planning 2011-2023. (Liepājas pilsētas teritoriālais plānojums 2011.-2023. gadam. I redakcija. Teritorijas izmantošanas un apbūves noteikumi. Liepāja: Grupa 93, 2011.)

Large-scale objects were included in Liepaja City environment. In New Liepaja library was liquidated, but on $28^{\text {th }}$ October, 1998 Olympic sports centre "Liepājas Metalurgs" ice hall was opened, as well as Liepaja Olympic Centre (2008) was created and Metallurgists' Culture Palace was rebuilding. In the northern part of city old production units were replaced with supermarket. Station Square was reconstructed (2011). Newly constructed buildings were laid out on the road Liepaja-Grobina.

In Old Liepaja historic environment were implemented a number of urban reconstruction projects. On $8^{\text {th }}$ February, 2001 the detailed plan of Seaside Park was affirmed (arch. Andris Kokins). 
Rose Square reconstruction project was developed (1999, arch. Andris Kokins), which was adjusted because of society protests (2001).

In the South-West district there was a living house complex "Rietumu krasts" (2009), supermarket "BAATA" (2009) built and other shopping places were created, however the same as in Ezerkrasts there are no public centre with culture objects.

Administrative borders of Liepaja City includes territory to South from Trade Canal to Pérkone River and part of Liepaja Lake with "Natura 2000" Special Protection Area, as well as the areas to the North - New Liepaja, Naval Port, Tosmare Lake and Beberlini reservoir, its shore is "Natura 2000" Special Protection Area. Main traffic roads are guided South-North direction: Uliha Street, which is nearby the coast of the Baltic Sea, joins Kurhaus Prospect and leads to New Tram Bridge, but Peas (Zirnuu) and Pasturable (Ganību) streets lead to the New Bridge in the locality of Liepaja Lake. There is the beginning of four main-roads from the North from canal: Raina Street leads to Naval Port, but Liberty Street and Farmers (Zemnieku) Street leads out of city. After closing of several railroad lines and dismantling of railway tracks New Liepaja diminished the significance of hub. City's green structure includes parks, squares, street greeneries and household gardens, as well as woods in the North part of city. In Liepaja during large scale street reconstruction (2011-2012) thousands of green trees were liquidated.

\section{CONCLUSIONS}

The Baltic Sea seashore cities Liepaja, Ventspils and Palanga are improved by different sustainable spatial development models. Specialization of economic sector has not been changed for Palanga. Clearly defined perspective of planning development in historical and contemporary construction territories is the advantage of chosen model for health resort.

Ventspils planning and functional zoning intends creation of specialized centers. The development model of export city and transit port clearly defines supermarket construction places with well-thoughtout, arranged territories of business and public institutions in the residential construction. The development of the green and technical construction zone happens purposefully and thought-out.

After liquidating and limiting several economic sectors in Liepaja, changing their specialization, a disproportion of production and residential territories has given. Perspectives of architectonic spatial environment development are unclear. Development of residential construction territories in New Liepaja, North suburb and Naval Port is not intended. Many family houses are located in inappropriate conditions, nearby industrial territories. Existing green areas are reconstructed, but creation of new parks and broadening of green zones in order to diminish the disadvantaged influence and to improve aesthetics of environment is not intended. To provide balanced development, it is necessary to improve the environment, preserving green areas and to create the development model of territorial planning for the complex solution of economic, social and environment problems, using the latest achievements of science, in order to stop the decrease of inhabitants in Liepaja. Showing the respect to achievement of previous generations, it is possible to create a sustainable development model of healthy city and to maintain identity of Liepaja.

\section{REFERENCES}

[1] Briṇkis J., Buka O. 2001. Teritoriālā plānošana un pilsētbūvniecība. Mācību grāmata. Rīga: RTU. [In Latvian]

[2] Jākobsone J. 2011. Vietējās identitātes - kultūrvēsturiskā mantojuma saglabāšanas ietekmējošie faktori līdzsvarotas attīstības kontekstā. Kuldīgas piemērs. In: RTU Zinātniskie raksti: 14. sērija. Ilgtspējīga telpiskā attīstība. Rīga: RTU, 2. sējums. [In Latvian]

[3] Liepājas pilsētas teritoriālais plānojums 2011.-2023. gadam. 2011. I redakcija. Liepāja: Grupa 93. [In Latvian]

[4] Vitāls A. 2009. „Jaunliepāja. Pilsēta - vide - cilvēks”. Prezentation. 20 ${ }^{\text {th }}$ March 2009. [In Latvian] 